\title{
Olgu Sunumu: Granulicatella adiacens Nedenli Menenjit
}

\section{Case Report: Meningitis Caused by Granulicatella adiacens}

\author{
Tug̃çe șiMȘEK BOZOK(IID)
}

Nig̃de Eg̃itim ve Araștırma Hastanesi, İnfeksiyon Hastalıkları ve Klinik Mikrobiyoloji Klinig̃i, Nig̃de, Türkiye

Makale atıf: Şimşek Bozok T. Olgu sunumu: Granulicatella adiacens nedenli menenjit. FLORA 2021;26(3):545-9.

\section{öz}

Nutrisyonel varyant streptokok (NVS) olarak adlandırılan Granulicatella adiacens cinsi bakteriler oral kavite, ürogenital ve gastrointestinal sistem florasının bir üyesidir ve standart laboratuvar teknikleriyle üretilmeleri zordur. Bu nedenle nadiren izole edilir. Daha çok infektif endokardit ve bakteriyemi vakalarında görülür. Ayrıca, yapılan çalısmalarda G. adiacens'e bağlı sepsis, septik artrit, protez infeksiyonu, beyin apsesi, osteomyelit geliştiği bildirilmiştir. Erişkinlerde akut bakteriyel menenjit etkenleri arasında sık görülen etkenler S. pneumoniae, N. meningitidis, L. monocytogenes, H. influenzae olup, bu etkenler dışındaki bakterilerin de azımsanmayacak oranda (\%13) etken olabileceği belirtilmiştir. Bu çalışmada G. adiacens'e bağlı bir menenjit olgusu sunulmaktadır.

Anahtar Kelimeler: Granulicatella adiacens; Menenjit; Nutrisyonel varyant streptokok

\section{ABSTRACT \\ Case Report: Meningitis Caused by Granulicatella adiacens}

\section{Tug̃çe șiMȘEK BOZOK}

Clinic of Infectious Diseases and Clinical Microbiology, Nig̃de Training and Research Hospital, Nig̃de, Turkey

Bacteria of the genus Granulicatella adiacens, called nutritional variant streptococci (NVS), are a member of the oral cavity, urogenital and gastrointestinal system flora and are difficult to produce by standard laboratory techniques. Therefore, it is rarely isolated. It is mostly seen in infective endocarditis and bacteremia cases. In addition, it has been reported that sepsis, septic arthritis, prosthesis infection, brain abscess, osteomyelitis developed due to G. adiacens. Among the causative agents of acute bacterial meningitis in adults, the most common agents are S. pneumoniae, N. meningitidis, L. monocytogenes, H. influenzae, and it has been stated that bacteria other than these agents may be causative agents (13\%). In this study, a case of meningitis due to G. adiacens is presented.

Key Words: Granulicatella adiacens; Meningitis; Nutritional variant streptococcus 


\section{Giriș}

Akut bakteriyel menenjit, meninks ve subaraknoid aralığın akut bir infeksiyonudur. Etiyolojik ajan, yașa ve altta yatan tıbbi koșullara, coğrafik bölgeye, toplum veya hastane kökenli olup olmamasına göre farkllılk göstermektedir. Meninkslere ulaşabilen her türlü bakteri etken olabilir ${ }^{[1]}$. Erișkinlerde bakteriyel menenjit vakalarının çoğuna Streptococcus pneumoniae neden olur. Pnömokok așıları yapılmaya bașlandıktan sonra vakalarda azalma gözlenmiștir. Neisseria meningitidis coğunlukla ergenlerde bulunur ve coğunlukla serogrup $\mathrm{B}$ görülür. Listeria monocytogenes eriskinlerde en yaygın üçüncü neden olup, daha çok yașlı ve immünsuprese hastalarda görülmektedir. Haemophilus influenzae ve Staphylococcus aureus, yetiskin vakaların \%1-2'sinde bulunur ve otitis ve sinüzit (H. influenzae) veya endokardit (S. aureus) gibi altta yatan spesifik durumlarla ilișkilidir ${ }^{[2]}$. Nutrisyonel varyant streptokoklar; Abiotrophia defectiva, Granulicatella adiacens ve Granulicatella elegans türlerinden olusan zor üreyen Gram-pozitif koklardır. Nutrisyonel varyant streptokoklar, daha cok önemli morbidite ve mortalite ile ilișkili bakteriyemi ve infektif endokarditin önemli bir nedenidir ${ }^{[3]}$. Yapılan calıșmalarda $G$. adiacens' in infektif endokardit, beyin absesi, vertebral osteomyelit, septik artrit, protez infeksiyonu olgularında izole edildiği belirtilmiștir ${ }^{[4-7]}$. Bu calıșmada $G$. adiacens'e bağlı olarak menenjit gelișen 39 yașında bir erkek hasta konu edilmistir.

\section{OLGU SUNUMU}

Kronik hastalığı olmayan, 39 yașındaki erkek hasta bir gün önce bașlayan baș ağrısı ve ateș nedeniyle acil servise bașvurdu. Hastanın anamnezinde; askerdeyken travma sonrası burun operasyonu geçirdiği, arada rinoresinin olduğu ve altı ay önce akut bakteriyel menenjit tanisıyla hastaneye yatırıldığı, BOS kültüründe üreme olmadığı ve ampirik 14 gün intravenöz antibiyotik tedavisi aldığı öğrenildi. Fizik muayenesinde; genel durum orta-iyi, bilinç açık, koopere, nabız 124/dakika, solunum sayıs1 24/dakika, arteryel kan basınc1 $135 / 85 \mathrm{mmHg}$, vücut sıcaklığ $39^{\circ} \mathrm{C}$, tonsiller doğal, solunum sesleri doğal, batın muayenesi ve kardiyolojik muayenesi doğald, ense sertliği pozitif, kerning negatif, brudzinski negatifti. Vücutta herhangi bir döküntü yoktu. Laboratuvar tetkikle- rinde; lökosit 32.400/ $\mathrm{mm}^{3}$ (nötrofil oranı \%93.4, lenfosit oranı \%3.5), hemoglobin $13.1 \mathrm{gr} / \mathrm{dL}$, platelet $220.000 / \mathrm{mm}^{3}$, kreatinin $1.1 \mathrm{mg} / \mathrm{dL}$, glukoz $180 \mathrm{mg} / \mathrm{dL}$, aspartat aminotransferaz $17 \mathrm{U} / \mathrm{L}$, alanin aminotransferaz $13 \mathrm{U} / \mathrm{L}, \mathrm{C}$-reaktif protein $255 \mathrm{mg} / \mathrm{L}$ (normal aralı 0-5 mg/L), Na: 136 $\mathrm{mmol} / \mathrm{L}, \quad \mathrm{K}$ : $3.9 \mathrm{mmol} / \mathrm{L}$, Beyin BT: normal, nöroloji tarafından lomber ponksiyon (LP) açısından kontrendikasyonu olmadığ 1 belirtilen hastaya LP yapıldı. BOS rengi bulanıktı, hücre sayımında 4800 lökosit $/ \mathrm{mm}^{3}$ görüldü. Giemsa boyamasında parçalı lökosit hakimiyeti görüldü, Gram boyamada bakteri görülmedi. BOS biyokimyas1; protein $58 \mathrm{mg} / \mathrm{L}$, LDH $25 \mathrm{U} / \mathrm{L}$, glukoz $66 \mathrm{mg} / \mathrm{dL}, \mathrm{Na}$ $142 \mathrm{mmol} / \mathrm{L}, \quad$ K $2.6 \mathrm{mmol} / \mathrm{L}$ olarak ölçüldü. BOS, kültür için koyun kanlı besiyerine, cikolata besiyerine ve $\mathrm{BD}$ Bactec PlusAerobic/F otomatize sistem kan kültürü sișesine (Becton Dickinson, Sparks, ABD) ekimi yapildı ve $37^{\circ} \mathrm{C}$ 'de inkübe edildi. Akut bakteriyel menenjit ön tanisıyla hasta kliniğimize yatırıldı. Ateși olduğunda bir set kan kültürü alınd. Ampirik seftriakson 2x2 gr intravenöz (IV) ve vankomisin $2 \times 1$ gr IV tedavi bașland. BOS'un besiyerlerine ekilmesinden 24 saat sonra koyun kanlı besiyeri ve cikolatalı besiyerinde seffaf, düzgün kenarl, alfa hemolitik koloniler üredi. $\mathrm{Bu}$ iki besiyerinden yapilan Gram boyamalarda, Gram-pozitif koklar görüldü. Ayrıca kan kültürü sisesinde 28 saat sonra üreme oldu ve buradan yapilan Gram boyamada da Gram-pozitif koklar görüldü. Bakteri identifikasyonu ve antibiyotik duyarlllik testleri otomatize Vitek 2 Compact (BioMerieux, Marcy l'Etoile, Fransa) sistemi ve AST-640 ve GP kartları kullanılarak yapıld1. Tanımlama sonucunda; Granulicatella adiacens tespit edildi ve antibiyotik duyarlllk test sonuçları; vankomisin, linezolid, moksifloksasin, levofloksasin, teikoplanin duyarlı, oksasilin, klindamisin, tetrasiklin, eritromisin dirençli olarak bulundu. Kan kültürlerinde üreme olmadi. Mevcut seftriakson ve vankomisin IV tedavisine devam edildi. Hastanın aralıklı rinoresinin olması nedeniyle beyin cerrahi bölümüne danıșıldı. Taburculuk sonrası sonrası poliklinik kontrolü önerildi ve cerrahi tedavinin gerekebileceği belirtildi. Tedavinin üçüncü günü alınan kontrol kan tetkiklerinde; lökosit 14600/ $\mathrm{mm}^{3}$ (nötrofil oranı \%78.5, lenfosit oran1 \%16.3), hemoglobin $13 \mathrm{gr} / \mathrm{dl}$, platelet $255.000 / \mathrm{mm}^{3}$, kreatinin $0.9 \mathrm{mg} / \mathrm{dl}$, glukoz $121 \mathrm{mg} / \mathrm{dL}$, aspartat 
aminotransferaz $11 \mathrm{U} / \mathrm{L}$, alanin aminotransferaz $19 \mathrm{U} / \mathrm{L}, \quad$ C-reaktif protein $30.3 \mathrm{mg} / \mathrm{dL}$, Na: $137 \mathrm{mmol} / \mathrm{L}, \quad \mathrm{K}: 4.5 \mathrm{mmol} / \mathrm{L}$ idi. Tedavinin 3. gününden itibaren ateși ve baș ağrısı belirgin gerileyen hastanın IV antibiyotik tedavisi 14 güne tamamlandı. Tam klinik iyileșme sağlanan hasta 14. günün sonunda sifa ile taburcu edildi. Rinoresi aralıklı olarak devam eden hastaya pnömokok, meningokok ve $H$. influenza tip B așları ve beyin cerrahi poliklinik kontrolü önerildi. On gün sonra kontrole gelen hastanın klinik olarak aktif sikayeti yoktu ve infeksiyon parametreleri normaldi. Rinoresi nedeniyle beyin cerrahi polikliniğinde hastanın değerlendirildiği, onarım için cerrahi tedavi önerildiği ancak hastanın dıș merkezde opere olmak istediği öğrenildi

\section{TARTIȘMA}

İlk olarak 1960'ların bașlarında endokardit vakalarından tarif edilen NVS'ler, 1990'ların ortasında ayrı bir cins, Abiotrophia olarak tanımlanmıstır ${ }^{[8,9]}$. Collins ve Lawson ise 2000 y1lında, 16S rRNA gen dizilimi temelinde NVS'leri Abiotrophia ve Granulicatella cinsleri olarak ayırmıștır. U̇c tür Granulicatella tanımlanmıștır: $G$. adiacens, $G$. elegans ve $G$. balaenopterae insan örneklerinde tespit edilmemiștir ${ }^{[10]}$. Granulicatella, katalaz negatif ve oksidaz negatif fakültatif anaerobik Gram-pozitif koklardır. NVS, sağlıklı oral flora, ürogenital sistem ve gastrointestinal sistem florasının bir üyesidir ${ }^{[4]}$. G. adiacens daha sık ağız boșluğunda görülür ve diș plaklarında, endodontik infeksiyonlarda ve dis apselerinde bulunur. Klinik olarak, NVS streptokok bakteriyemi vakalarının $\% 2.3$ 'ünü ve streptokokal endokardit vakalarının \%5'ini olușturmaktadır[11]. NVS'ye bağlı infeksiyonlar, sık görülmemekle birlikte genellikle önemli morbidite ve mortalite ile ilișkilidir. Endokarditin yanı sıra, NVS bakteriyemi, septisemi, merkezi sinir sistemi infeksiyonları, oküler infeksiyonlar ve solunum yolu infeksiyonları gibi ceșitli diğer infeksiyonlarda da rol oynamaktadir ${ }^{[12]}$.

NVS'lerin izolasyon oranları, piridoksal ve L sistein içeren BacT Alert ${ }^{\circledR}$ kültür șișeleri gibi ticari besiyerinin kullanımının artmasıyla beraber artıș göstermiștir. İncelenen vakaların coğunda, NVS otomatik kültür șișelerinden izole edilmiștir ${ }^{[6]}$. G. adiacens, alfa-hemolitik streptokok olup yavaș büyüyen koloniler olușturur. Kanlı agar besiyeri- ne piridoksal eklendiğinde $S$. aureus sușlarının etrafında uydu koloniler olușturur ${ }^{[10,11]}$. Gupta ve arkadașları tarafından bildirilen iki olguda koyun kanlı agar, MacConkey agar ve cikolata agar ekilen apse materyallerinde yedi günlük inkübasyona rağmen üreme tespit edilmemiş olup zenginlestirilmis kan kültür sisesine ekilen apse materyalinde 28-32 saatte üreme sinyali olduğu bildirilmiștir ${ }^{[6]}$.

Padmaja ve arkadașları 2014 yılında 48 yasında önceden kalp anomalisi olmayan bir kadın hastada $G$. adiacens'e bağlı infektif endokardit ${ }^{[12]}$, Aweid ve arkadașları 2016 yılında 81 yașında bir hastanın antibiyotik profilaksisi almadan olduğu diș tedavisi sonrası $G$. adiacens'e bağlı kalça protez infeksiyonu[13], Sendi ve arkadașları 2018 yılında 32 yașında konjenital kalp hastalığı olan bir kadın hastada, G. adiacens'in etken olduğu kardiyak implante edilebilir elektronik cihazla ilișkili infeksiyon ve biyoprotez endokardit ${ }^{[14]}$, Gupta ve arkadașları tarafından iki vakanın sunulduğu bir çalıșmada, 30 yașında herhangi bir travma ya da operasyon öyküsü olmayan bir erkek hastada $G$. adiacens'e bağlı sağ dizde septik artrit ve 18 yasında bir erkek hastada sağ dirsekte abse ${ }^{[6]}$, Gardenier ve arkadașları 89 yassında bir kadın hastada trafik kazasından (bilateral alt ekstremitelerde fraktür, entübe olan hasta) bir hafta sonra $G$. adiacens'e bağlı sepsis ${ }^{[15]}$, Ku ve arkadașları 2015'te 45 yașında bir kadın hastada $G$. adiacens'in etken olduğu kronik dakriosistit ${ }^{[16]}$, Alkan Çeviker ve arkadașları 2019'da G. adiacens'e bağlı omuz cerrahisi sonrası gelișen septik artrit ${ }^{[17]}$, Sachin ve arkadașları 2019'da yapılan bașka bir calıșmada G. adiacens'e bağlı lomber osteomyelit ve beyin absesinin eșlik ettiği doğal kapak infektif endokar$\mathrm{dit}^{[4]}$, York ve arkadașları 2016'da bir ay önce diș operasyonu geciren bir olguda $G$. adiacens'e bağlı vertebral osteomyelit ${ }^{[5]}$, 2016'da Maçin ve arkadașları iki olgu sundukları çalısmalarında 61 yașında diabetik, malignensisi olan erkek hastada G. adiacens nedenli mandibular osteomyelit ve 18 yașındaki $\mathrm{T}$ hücreli lenfoblastik lenfoması olan ve kemoterapi alan bir hastada $G$. adiacens'e bağll sepsis ${ }^{[18]}$ geliștiğini bildirmișlerdir. Klinik izolat kaynağını içeren en büyük seride, kaynağı bilinen 43 G. adiacens izolatından 39'u kandan, geri kalanı sinüs, kemik iliği, apseler ve göz örneklerinden izole edilmiștir ${ }^{[19]}$. Sunulan olguda, akut bakteri- 
yel menenjit ön tanısıyla yatırdığımız hastamızın beyin omurilik sıvisından $G$. adiacens izole edildi. Ulașabildiğimiz kaynak taraması sonucunda ülkemizde $G$. adiacens'e bağlı menenjit olgusuna rastlanmadi. Ancak İspanya'da 2020 yılında yapilan bir calıșmada medulloblastom cerrahisi sonrası $G$. adiacens'e bağlı menenjit olgusu bildirilmiștir ${ }^{[20]}$.

Yapılan bir çalısmada; 2008'den 2014'e kadar toplam 132 klinik NVS kan izolatı test edilmiș ve NVS izolatlarının tür düzeyinde tanımlanması, 16S rRNA gen siralaması ve/veya matris destekli lazer desorpsiyon iyonizasyonu-uçus zamanı kütle spektrometrisi (MALDI-TOF MS) ile gerçekleștirilmiștir. 90 izolat $G$. adiacens, 37'si $A$. defectiva ve beși $G$. elegans olarak belirlenmiș. Tüm izolatların vankomisine (MIC $901 \mathrm{~g} / \mathrm{ml}$ ) duyarlı olduğu ve hichbirinin aminoglikozidlere karșı yüksek düzeyde direnç göstermediŏi belirtilmiștir. G. adiacens, penisiline $A$. defectiva'dan (izolatların \%10.8'ine karșı duyarlı) önemli ölçüde daha duyarlı, ancak sefalosporinlere $A$. defectiva'dan daha az duyarl (seftriaksona duyarlı izolatların \%43.3'üne karșı \%100) olarak bulunmustur ${ }^{[3]}$. Literatürde ceșitli klinik örneklerden izole edilen $G$. adiacens suslarının \%38.9'unun penisiline [ancak cok sayida izolat (\%47.8) orta derecede duyarl1], \%18.9'unun sefotaksime, \%43.3'ünün seftriaksona, \%52.2'sinin eritromisine, \%84.5'inin klindamisine, \%91.9'unun levofloksasine ve tümünün meropenem ve vankomisine duyarlı olduğu bildirilmiștir ${ }^{[3,6,11,17]}$. Olgumuzda akut bakteriyel menenjit ön tanisiyla ampirik olarak başlanılan seftriakson ve vankomisin tedavisine devam edildi ve klinik olarak tam iyileșme sağland.

Erișkinlerde akut bakteriyel menenjit etkenleri arasinda en sik S. pneumoniae (\%53), N. meningitidis (\%27), L. monocytogenes (\%4), H. influenzae (\%3) yer almaktadır. Ancak bu etkenler dișındaki bakterilerin de azımsanmayacak oranda (\%13) etken olabileceği belirtilmiștir ${ }^{[2]}$. Menenjit etkenleri arasında nadir görülen bir etken olan $G$. adiacens'in etken olduğunu ve sık görülen bakteriyel ajanlar yanında bu etkenlerin de akılda tutulması gerektiği sonucuna varılmıștır. Normal floranın bir üyesi olmasına rağmen bu organizmanın patojen olabileceği akılda tutulmalıdır. Diğer taraftan, zayıf kolonileri ve zenginleștirilmemiș besiyerinde ürememeleri nedeniyle kolayca gözden kaçabilirler. Tüm bu nedenlerden dolayı, bu güc üreyen organizmaları izole etmek için uygun desteklenmiș ortam ve güvenilir bir tespit sistemi kullanılmalıdır.

\section{ÇIKAR ÇATIȘMASI}

Yazar bu makale ile ilgili herhangi bir çkar çatıșması bildirmemiștir.

\section{YAZAR KATKISI}

Anafikir/Planlama: TŞB

Analiz/Yorum: TȘB

Veri sağlama: TȘB

Yazım: TSSB

Gözden Geçirme ve Düzeltme: TŞB

Onaylama: TȘB

\section{KAYNAKLAR}

1. Tülek N, Taşdelen Fışgın N. Akut bakteriyel menenjitler. In: Willke Topçu A, Söyletir G, Doğanay M (eds). Enfeksiyon hastalıkları ve Mikrobiyolojisi. $4^{\text {th }}$ ed. Istanbul: Nobel Tıp Kitabevleri. 2017:1275-303.

2. Van de Beek D, Cabellos C, Dzupova O, Esposito S, Klein $M$, Kloek $A T$, et al. ESCMID guideline: diagnosis and treatment of acute bacterial meningitis. Clin Microbiol Infect 2016;22:37-62

3. Alberti MO, Hindler JA, Humphries RM. Antimicrobial susceptibilities of Abiotrophia defectiva, Granulicatella adiacens, and Granulicatella elegans. Antimicrob Agents Chemother 2015;60:1411-20.

4. Patil SM, Arora N, Nilsson P, Yasar SJ, Dandachi D, Salzer WL. Native valve infective endocarditis with osteomyelitis and brain abscess caused by Granulicatella adiacens with literature review. Case Rep Infect Dis 2019:4962392.

5. York J, Fisahn C, Chapman J. Vertebral osteomyelitis due to Granulicatella adiacens, a nutritionally variant Streptococci. Cureus 2016;8:e808.

6. Gupta S, Garg M, Misra S, Singhal S. Granulicatella adiacens abscess: Two rare cases and review. I Lab Physicians 2018;10:121-3.

7. Quénard F, Seng P, Lagier JC, Fenollar F, Stein A. Prosthetic joint infection caused by Granulicatella adiacens: a case series and review of literature. BMC Musculoskelet Disord 2017;18:276.

8. Frenkel A, Hirsch W. Spontaneous development of $L$ for$m s$ of streptococci requiring secretions of other bacteria or sulphydryl compounds for normal growth. Nature 1961;191:728-30.

9. Kawamura Y, Hou XG, Sultana F, Liu S, Yamamoto H, Ezaki T. Transfer of Streptococcus adjacens and Streptococcus defectivus to Abiotrophia gen. nov. as Abiotrophia adiacens comb. nov. and Abiotrophia defectiva comb. nov., respectively. Int J Syst Bacteriol 1995;45:798-803. 
10. Collins MD, Lawson PA. The genus Abiotrophia (Kawamura et al.) is not monophyletic: proposal of Granulicatella gen. nov., Granulicatella adiacens comb. nov., Granulicatella elegans comb. nov. and Granulicatella balaenopterae comb. nov. Int J Syst Evol Microbiol 2000;50:365-9.

11. Cargill JS, Scott KS, GascoyneBinzi D, Sandoe JA. Granulicatella infection: Diagnosis and management. I Med Microbiol 2012;61:75561.

12. Padmaja K, Lakshmi V, Subramanian S, Neeraja M, Krishna $S R$, Satish OS. Infective endocarditis due to Granulicatella adiacens: a case report and review. I Infect Dev Ctries 2014:8:548-50.

13. Aweid $\mathrm{O}$, Sundararajan S, Teferi A. Granulicatella adiacens prosthetic hip joint infection after dental treatment. JMM Case Rep 2016;3:e005044.

14. Sendi P, Wustmann K, Büchi AE, Noti F, Klaeser B, Sonderegger B, et al. Cardiac implantable electronic device-related infection due to Granulicatella adiacens. Open Forum Infect Dis 2019;6:130.

15. Gardenier JC, Hranjec T, Sawyer RG, Bonatti H. Granulicatella adiacens bacteremia in an elderly trauma patient. Surg Infect (Larchmt) 2011;12:251-3.

16. Ku CA, Forcina B, LaSala PR, Nguyen I. Granulicatella adiacens, an unusual causative agent in chronic dacryocystitis. J Ophthalmic Inflamm Infect 2015;5:12.
17. Çeviker SA, Günal O, Kılıç SS. Granulicatella adiacens'e bağlı omuz cerrahisi sonrası gelişen septik artrit. Flora 2019:24:152-6.

18. Macin S, Inkaya AÇ, Tuncer Ö, Ünal S, Akyön Y. Infections related to Granulicatella adiacens: Report of two cases and review of literature. Indian I Med Microbiol 2016;34:54750.

19. Christensen JJ, Facklam RR. Granulicatella and Abiotrophia species from human clinical specimens. I Clin Microbiol 2001;39:3520-3.

20. González-Haba-Martínez B, Sánchez-Códez MI, Lubián-Gutiérrez M. Meningitis caused by Granulicatella adiacens after medulloblastoma surgery. Med Clin (Barc) 2020:S0025-7753(20)30543-1.

\section{Yazıșma Adresi/Address for Correspondence}

Dr. Tuğçe ȘIMȘEK BOZOK

Niğde Eğitim ve Araștırma Hastanesi,

İnfeksiyon Hastalıkları ve

Klinik Mikrobiyoloji Kliniği,

Niğde-Türkiye

E-posta: tugce_0103@hotmail.com 